\title{
Penerapan Pembelajaran dengan E-Modul Berbasis Kvisoft Flipbook Maker untuk Mata Kuliah Program Linier
}

\author{
Soffi Widyanesti Priwantoro, Burhan Arif, Syariful Fahmi \\ Universitas Ahmad Dahlan, Jogjakarta \\ *Correspondence adress: soffiwidyanesti@pmat.uad.ac.id
}

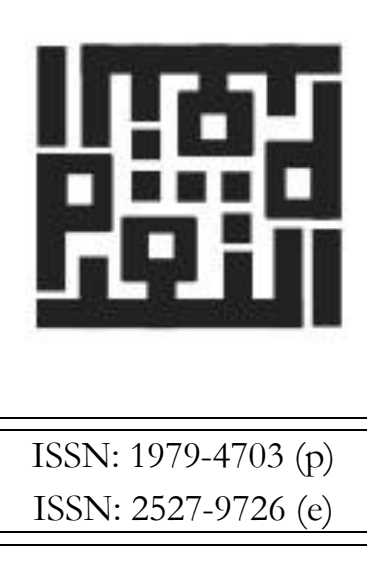

Keywords:

kemandirian, kvisof, media

\section{A B S T RACT}

This study aims to improve the independence of students in learning Linear Program by using e-module learning media linear program based on Kvisoft Flipbook Maker. This research is a Classroom Action Research (CAR). This research was conducted in the mathematics education study program FKIP UAD. The results of this study indicate an increase in student learning independence, this is evidenced by the results of interviews with students who showed positive responses. In addition from the observations also obtained a positive response that is the first cycle the average score of learning independence of $52.52 \%$ in the second cycle increased by $62.21 \%$ and in the third cycle of 72.21\%. As well as an increase in completeness of learning outcomes in the first cycle by $50 \%$, then the second cycle increased by $61.53 \%$ and in the third cycle of $76.9 \%$.

\section{A B S T R A K}

Penelitian ini bertujuan untuk meningkatkan kemandirian mahasiswa dalam pembelajaran Program Linier dengan menggunakan media pembelajaran e-modul program linier yang berbasis kvisoft flipbook maker. Penelitian ini merupakan Penelitian Tindakan Kelas (PTK). Penelitian ini dilaksanakan di program studi pendidikan matematika FKIP UAD. Hasil penelitian ini menunjukkan adanya peningkatan kemandirian belajar mahasswa, hal ini dibuktikan dengan hasil wawancara terhadap mahasiswa yang menunjukkan respon positif. Selain itu dari hasil observasi juga diperoleh respon yang positif yaitu siklus I rata-rata skor kemandirian belajar sebesar $52,52 \%$ pada siklus II meningkat sebesar 62,21\% dan pada siklus III sebesar 72,21\%. Serta adanya peningkatan ketuntasan hasil belajar yaitu pada siklus I sebesar $50 \%$, kemudian siklus II meningkat $61,53 \%$ dan pada siklus III sebesar $76,9 \%$. 


\section{Pendahuluan}

Matematika sebagai ilmu dasar mempunyai peran penting dalam perkembangan ilmu pengetahuan dan teknologi. Untuk memahami konsep matemtatika secara mendalam terlebih dahulu harus memahami konsep dasar matematika. Secara umum karakterisktik matematika adalah obyek kajian yang abstrak, berhubungan dengan ide, proses dan penalaran serta berkaitan dengan konsep-konsep pembuktian yang logis (Suherman, 2003:17). Hal ini menuntut mahasiswa untuk bersikap cermat, teliti dan tekun agar keberhasilan dalam belajar matematika dapat tercapai. Ada beberapa faktor yang mempengaruhi keberhasilan belajar, salah satunya adalah kemandirian dalam belajar (Fariyani, 2019). Kemandirian belajar adalah keadaan dari seseorang untuk berusaha belajar mandiri dengan kemampuan yang dimiliki, mampu untuk belajar dengan inisiatif sendiri dalam hal penentuan tujuan belajar, metode belajar setra memiliki semangat yang muncul dari diri sendiri tanpa ada paksaaan dari pihak lain. Seorang mahasiswa yang memiliki keinginan untuk belajar mandiri berarti sudah menyadari pentingnya meningkatkan hasil belajar. Kemandirian belajar merupakan salah satu faktor penting yang harus dimiliki mahasiswa guna meningkatkan hasil belajar (Ardi, 2015:495).

Program linier merupakan salah satu mata kuliah yang harus dipelajari oleh mahasiswa Pendidikan Matematika di semester lima dengan bobot 3 sks. Mata kuliah ini merupakan mata kuliah lanjutan dengan mata kuliah prasyarat aljabar elementer dan aljabar matrik. Pada mata kuliah ini diharuskan mahasiswa untuk benar-benar memahami materi program linier karena materi ini sebagai bekal mahasiswa untuk mengajar di sekolah. Permasalahan yang muncul berkaitan dengan materi diantaranya mahasiswa mengalami kesulitan dalam memodelkan permasalahan matematika, menentukan daerah layak dari beberapa kendala program linier, dan menentukan garis selidik. Sedangkan pada proses pembelajaran diantaranya beberapa mahasiswa menunggu penjelasan dari dosen, mahasiswa tidak membawa buku referensi yang dianjurkan di awal pertemuan, mahasiswa tidak mau mengerjakan soal latihan di depan kelas, mahasiswa menunggu perintah dari dosen untuk mengerjakan soal latihan. Berdasarkan hasil wawancara dengan mahasiswa di kelas, bahwa mata kuliah program linier dianggap sebagai mata kuliah yang membutuhkan proses simulasi visualisasi dalam bentuk gambar, sedangkan buku referensi yang ada belum ada proses simulasi penyelesaian dari soal program linier. Hal ini membuat dosen harus memilih media yang menarik untuk dapat mensimulasikan proses penyelesaian permasalahan matematika yang berkaitan dengan program linier.

Berdasarkan hasil observasi dan wawancara terhadap mahasiswa pendidikan matematika diperoleh ide untuk meningkatkan kemandirian mahasiswa dalam belajar dengan menggunakan media pembelajaran yang dapat mensimulasikan proses penyelesaian permasalahan program linier. Mandiri dalam belajar sangat penting dimiliki oleh mahasiswa karena dengan kemandirian dapat mempersiapkan dan menghadapai masalah yang lain dalam hidup (cristina, 2015). Media yang digunakan dalam membantu kegiatan proses pembelajaran adalah media yang berbasis teknologi (Nurfalah, 2019). Dengan menggunakan teknologi dapat menumbuhkan pembelajaran yang inovatif dan 
sikap mandiri dalam belajar bagi mahasiswa (prieto, 2015). Dengan latar belakang yang telah diuraikan diatas untuk mengatasi permasalahann tersebut, akan dilakukan suatu penelitian tindakan untuk meningkatkan kemandirian mahasiswa dalam perkuliahan program linier dengan menggunakan e-modul program linier yang berbasis kvisoft flipbook maker.

\section{Metode Penelitian}

Jenis Penelitian ini adalah penelitian kualitatif, yang menghasilkan penelitian dengan data deskriptif berupa kata-kata tertulis atau lisan tentang perilaku yang diamati sehingga dapat menemukan kebenaran yang dapat diterima akal sehat. Penelitian Tindakan Kelas termasuk penelitian kualittatif meskipun data yang dikumpulkan bisa saja berifat kuantitatif dengan uraiannya bersifat deskriptif dalam bentuk uraian kata-kata, dengan peneliti merupakan instrument pertama dalam pengumpulan data, proses sama pentingnya dnegan produk (Kunanda, 2008). Adapun tahapan-tahapan dalam penelitian meliputi:

a. Tahap perencanaan, meliputi: pembuatan proposal; pengajuan proposal penelitian; pembuatan instrumen penelitian yang terdiri atas lembar angket kemandirian mahasiswa, soal tes akhir siklus, dan pedoman wawancara; pembuatan perangkat pembelajaran yaitu Rencana Pembelajaran Semester (RPS)

b. Tahap pelaksanaan, meliputi: semua kegiatan yang dilaksanakan di lokasi penelitian, seperti pelaksanaan dari RPS yang telah disusun, pengamatan pembelajaran oleh peneliti dan observer, serta pengambilan data untuk dianalisis.

c. Tahap penyelesaian, meliputi: refleksi yaitu peneliti dan observer melakukan analisis terhadap hasil pengamatan selama kegiatan proses pembelajaran berlangsung, penyusunan tindakan untuk siklus II yang memungkinkan perubahan ataupun pengembangan tindakan dari apa yang telah dilakukan pada siklus I. Sampai pada refleksi ini, maka PTK telah berjalan satu siklus. Pada dasarnya, tahap-tahap yang dilaksanakan pada siklus II sama dengan tahap-tahap pada siklus I. Selain itu, pada tahap penyelesaian ini juga dilakukan pengolahan data dan penyusunan laporan penelitian.

Kegiatan penelitian ini akan dilakukan dengan mekanisme seperti dalam alur penelitian yang tergambar dalam diagram fishbone berikut. 


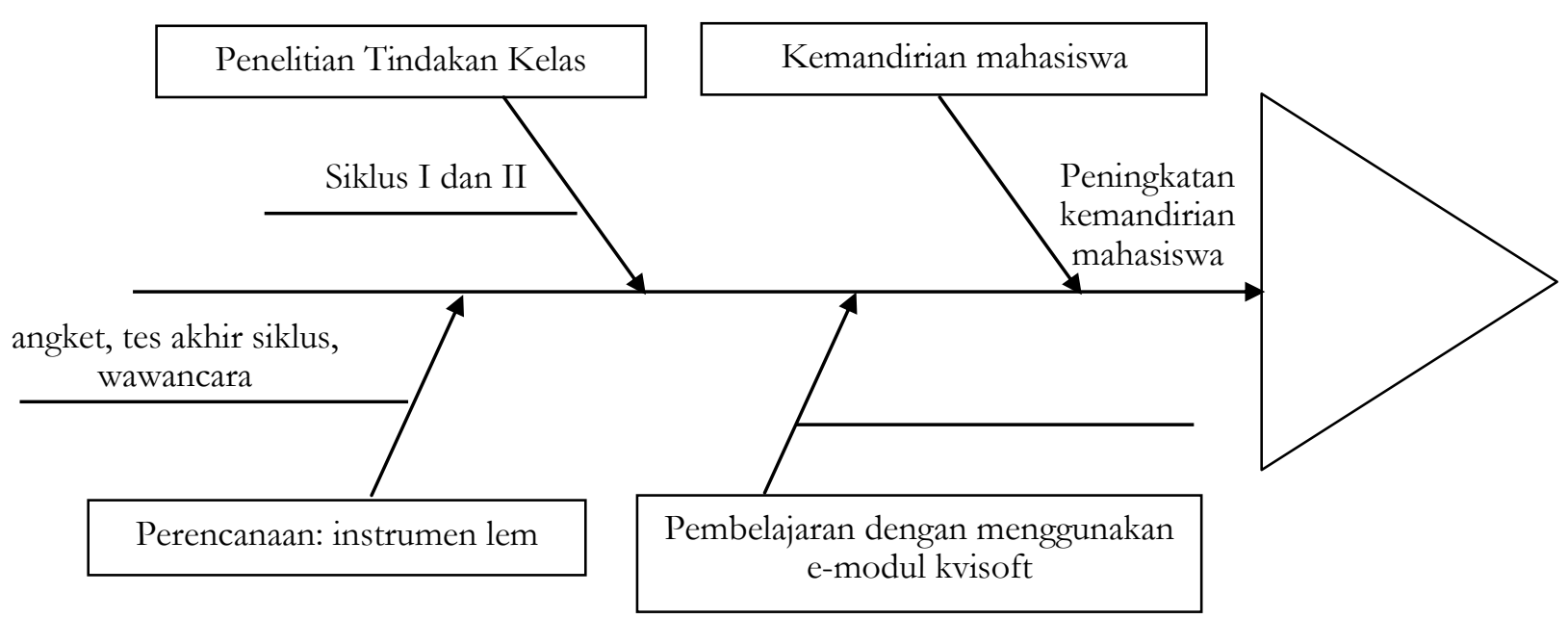

\section{Gambar 1. Fishbone alur Penelitian}

\section{Teknik Pengumpulan Data}

Teknik pengumpulan data dalam penelitian ini dilakukan dengan cara:

a. Observasi

Metode observasi dilakukan untuk mengamati secara langsung keaktifan mahasiswa selama proses pembalajaran Program Linier dengan menggunakan emodul berbasis kvisoft Flipbook Maker. Dalam melakukan observasi, peneliti menggunakan lembar observasi keaktifan belajar mahasiswa. Menurut Arikunto (1985:130), dalam menggunakan metode observasi, cara yang paling efektif adalah melengkapinya dengan format atau blangko pengamatan sebagai instrumen. Keuntungan dari metode observasi adalah metode ini memungkinkan pencatatan saat berlangsungnya pembelajaran di kelas (Hadi, 2004: 175).

b. Tes Akhir Siklus

Tes ini berisi soal-soal penyelesaian program linier dengan menggunakan metode grafik dan garis selidik yang harus diselesaikan oleh setiap mahasiswa secara mandiri. Tes ini diberikan disetiap akhir siklus.

c. Wawancara

Wawancara dilakukan setelah siklus terakhir dilaksanakan. Beberapa mahasiswa diberikan pertanyaan mengacu pada pedoman wawancara.

d. Instrumen Penelitian

Instrumen yang digunakan dalam penelitian ini adalah sebagai berikut:

e. Lembar Observasi

Lembar observasi berfungsi untuk mencatat tingkah laku, persitiwa, serta semua hal yang dianggap penting yang dilkakukan oleh mahasiswa dalam penelitian dan digunakan untuk mendapatkan gambaran yang lebih kongkrit. Lembar observasi 
berisi indikator kemandirian belajar meliputi : mengambil inisiatif untuk bertindak, menghargai hasil karya sendiri, memberdayakan kemampuan yang dimiliki, memiliki kepercayaan diri.

f. Lembar Wawancara

Wawancara dilakukan kepada mahasiswa dengan kisi-kisi diantaranya tanggapan mahasiswa terhadap proses pembelajaran, pemahaman materi, kendala dalam proses pembelajaran, kemampuan menyelesaikan masalah dan saran mahasiswa terhadap proses pembelajaran.

g. Dokumentasi

Dokumen dilakukan dengan kamera dan tulisan, untuk mengambil gambar selama proses pembelajaran berlangsung.

h. Catatan Lapangan

Catatan lapangan diperoleh dari apa yang dilihat, didengar dan dialamai dalam rangka pemgumpulan data dan refleksi terhadap data dalam penelitian.

i. Soal Tes Akhir Siklus

Soal tes akhir siklus berisi soal-soal bentuk uraian yang bersesuaian dengan materi yang dipelajari saat proses pembelajaran.

\section{Analisis Data dan Penarikan Kesimpulan}

Analisis data dilakukan sejak peneliti memperoleh data dari hasil observasi oleh peneliti. Data hasil penelitian dianalisis secara deskriptif untuk tiap siklus. Hal ini berguna dalam rencana perbaikan pembelajaran pada siklus berikutnya.

a. Analisis data observasi

Hasil observasi tentang pelaksanaan pembelajaran dianalisis secara deskriptif untuk perbaikan dalam pembelajaran berikutnya.

Data hasil obervasi kemandirian belajar mahasiswa dapat dihitung sebagai berikut:

$$
p=\frac{\sum_{i=1}^{k} n_{i}}{N}
$$

keterangan :

$\mathrm{n}$ : Jumlah skor mahasiswa

$\mathrm{N}$ : Jumlah maksimal skor mahasiswa

$\mathrm{k}$ : Banyaknya mahasiswa

Selanjutnya data kuantitatif tersebut dapat ditafsirkan dengan kalimat kualitatif.

Tabel 1. Kualitatif Hasil Lembar Angket Mahasiswa

\begin{tabular}{ll}
\hline \multicolumn{1}{c}{ Presentase } & \multicolumn{1}{c}{ Kriteria } \\
\hline $80 \%<\mathrm{P} \leq 100 \%$ & Sangat Baik \\
$60 \%<\mathrm{P} \leq 80 \%$ & Baik \\
$40 \%<\mathrm{P} \leq 60 \%$ & Cukup \\
$20 \%<\mathrm{P} \leq 40 \%$ & Kurang \\
\hline
\end{tabular}




\begin{tabular}{ll}
\hline $0 \%<\mathrm{P} \leq 20 \%$ & Kurang Sekali \\
\hline
\end{tabular}

Sumber: Riduwan (2011:41)

a. Analisis data tes akhir siklus

Menghitung skor pada setiap butir soal sesuai pedoman penskoran yang telah disusun.

b. Reduksi data

Kegiatan dalam reduksi data yaitu kegiatan memfokuskan, menyederhanakan, dan mentransfer data kasar ke catatan lapangan.

c. Triangulasi

Triangulasi dilakukan dengan membandingkan data hasil observasi, wawancara dan catatan lapangan. Triangulasi sekaligus digunakan untuk memeriksa keabsahan data.

d. Display data

Data hasil reduksi dan triangulasi disajikan dalam bentuk deskripsi, tabel atau grafik

e. Penarikan kesimpulan

Dari data-data yang diperoleh kemudian diambil suatu kesimpulan.

\section{Hasil dan Pembahasan}

\section{Hasil dan Pembahasan Siklus I.}

\section{Tahap Perencanaan}

Pada tahap ini, peneliti mempersiapkan instrument penelitian yang berupa lembar observasi kemandirian belajar mahasiswa dengan menggunakan e-modul berbasis kvisoft flipbook maker, soal tes akhir siklus 1, Pembuatan perangkat pembelajaran yaitu Rencana Pembelajaran Semester (RPS). Materi yang dibahas pada siklus 1 ini adalah memodelkan masalah program linier.

\section{Tahap Pelaksanaan}

Tahap ini merupakan pelaksanaan pembelajaran dengan menggunakan e-modul yang berbasis kvisoft flipbook maker, sehingga data penelitian diperoleh dari hasil observasi kemandirian belajar mahasiswa dengan menggunakan e-modul kvisoft flipbook. maker, oleh observer. Data yang diambil dari tahap ini berupa presentase kemadnirian bekajar mahasiswa dalam proses pembelajaran serta hasil tes akhir siklus 1. Persentase kemandirian belajar mahasiswa dalam proses pembelajaran pada setiap siklus dirumuskan sebagai berikut. Data hasil observasi kemandirian belajar mahasiswa dapat dihitung sebagai berikut. 


$$
p=\frac{\sum_{i=1}^{k} n_{i}}{N}
$$

keterangan :

$\mathrm{n}:$ Jumlah skor mahasiswa

$\mathrm{N}$ : Jumlah maksimal skor mahasiswa

$\mathrm{k}$ : Banyaknya mahasiswa

Hasil observasi kemandirian belajar mahasiswa pada siklus I, dapat dilihat pada tabel berikut ini.

Tabel 2 Hasil analisis Kemandirian Belajar Mahasiswa Siklus I.

\begin{tabular}{cll}
\hline No. & Indikator & Siklus I \\
\hline 1. & Mengambil inisiatif untuk bertindak & $63,89 \%$ \\
2. & menghargai hasil karya sendiri, & $37,03 \%$ \\
3. & memberdayakan kemampuan yang dimiliki, & $55,5 \%$ \\
4. & memiliki kepercayaan diri & $44,4 \%$ \\
& Jumlah & $52,52 \%$ \\
\hline
\end{tabular}

Tabel diatas menyatakan persentase kemandirian belajar mahasiswa sebesar $52,52 \%$ dalam kategori cukup. Pada siklus I terdapat bebebrapa indikator pada kategori kurang yaitu indikator mengenai menghargai hasil karya sendiri, dari pengamatan pada siklus satu terlihat sebagian besar mahasiswa masih mengalami kesulitan dalam memahami e-modul, terkadang mahasiswa tidak membuka video yang sudah tersedia pada aplikasi sehingga mahasiswa cenderung meniru jawaban milik temannya. Terdapat beberapa indikator yang masuk dalam kategori cukup yaitu memberdayakan kemampuan dan memiliki kepercayaan diri. Pada siklus 1 dosen masih menjelaskan hampir $80 \%$ mengenai materi memodelkan masalah matematika, sehingga mahasiswa belum menggunakan e-modul secara keseluruhan. Dalam hal memecahkan masalah mahasiswa masih bergantung keapada penjelasan dari dosen walaupun pemecahan masalah tersebut sudah dijelaskan pada e-modul. Selain data hasil observasi, pada tahap ini juga dilaksanakan tes akhir siklus untuk mengukur hasil belajar mahasiswa dengan penerapan pembelajaran menggunakan kvisoft flipbook maker. Dengan menetapkan nilai ketuntasan minimal sebesar 60. Dari hasil tes akhir siklus diperoleh sebanyak 13 mahasiswa tuntas sedangkan ada 13 mahasiswa belum tuntas. Presentase ketuntasan sebesar $50 \%$. 


\section{At-Taqaddum}

Vol. 12 No. 1 (2020) 1-12

\section{Tahap Refleksi}

Pada tahap ini dilakukan refleksi atau evaluasi dari pelaksanaan siklus 1. Dari hasil observasi kemandirian belajar mahasiswa diperoleh 2,52\% pada kategori cukup. Secara kuantitatif $50 \%$ mahasiswa tuntas, hal ini masih belum memenuhi kategori keberhasilam yaitu lebih dari $60 \%$ mahasiswa mencapai nilai tuntas. Hasil ini mengatakan bahwa siklus 1 belum berhasil Ada beberapa indikator yang perlu ditekankan yaitu mengenai penggunaan e-modul secara lebih detail sehingga mahasiswa dapat membuka e-modul sebelum perkuliahan dimulai. Selain itu mengingatkan mahasiswa untuk mempelajari emodul secara seksama dengan menonton video yang tersedia pada e-modul.

\section{Hasil dan Pembahasan Siklus 2}

\section{Tahap Perencanaan}

Pada tahap ini, telah dipersiapkan instrumen penelitian yang berupa lembar observasi kemandirian belajar mahasiswa dengan menerapkan pembelajaran menggunakan e-modul berbebasis kvisoft flipbook maker, soal tes akhir siklus 2, kuis, pembuatan perangkat pembelajaran yang terdiri atas rencana pembelajaran semester (RPS). Materi yang dibahas pada siklus 2 ini adalah Menyelesaikan Program Linier dengan menggunakan metode grafik.

\section{Tahap Pelaksanaan}

Tahap ini adalah pelaksanaan pembelajaran menggunakan e-modul berbasis kvisoft flipbook maker, sehingga data penelitian diperoleh dari hasil observasi kemnadirian belajar mahasiswa dengan menerapkan pembelajaran menggunakan e-modul berbasis kvisoft flipbook maker oleh observer. Adapaun data yang diambil dari tahap ini berupa persentase kemandirian belajar mahasisswa dalam kegiatan pembelajaran serta hasil tes akhir siklus 2. Selengkapnya hasil observasi kemandirian belajar mahasiswa pada siklus 2 seperti tabel berikut.

\section{Tabel 3 Hasil Analisis Kemandirian Belajar Mahasiswa siklus 2}

\begin{tabular}{lll}
\hline No. & Indikator & Siklus I \\
\hline 1. & Mengambil inisiatif untuk bertindak & $78,7 \%$ \\
2. & menghargai hasil karya sendiri, & $50 \%$ \\
3. & memberdayakan kemampuan yang dimiliki, & $64,81 \%$ \\
4. & memiliki kepercayaan diri & $55,5 \%$ \\
Jumlah & $62,25 \%$ \\
\hline
\end{tabular}

Berdasarkan tabel diperoleh hasil observasi Kemandirian Belajar Mahasiswa sebesar 62,25\% pada kategori baik. Pada siklus 2 ini persentase setiap indikator mengalami peningkatan. Terdapat dua indikator pada kategori cukup dan 1 indikator 
dalam kategori baik dan 1 indikator pada kategori sangat baik. Pada siklus dua ini, dosen lebih mengurangi penjelasan dalam kelas sehingga penggunaan e-modul dapat mencapai $75 \%$. Dosen hanya menjawab pertanyaan jika ada mahasiswa yang merasa kesulitan dalam memahami video penjelasan yang termuat dalam e-modul. Hasil belajar mahasiswa pada materi menyelesaikan masalah program linier dengan menggunakan metode grafik diperoleh dari res akhir siklus 2 yaitu 16 mahasisswa mendapatkan nilai tuntas dan 10 mahasiswa belum tuntas. Dengan persentase ketuntasan sebesar 61,53\%.

\section{Tahap Refleksi}

Pada tahap ini dilakukan refleksi atau evaluasi dari pelaksanaan siklus 2. Dari hasil observasi kemandirian belajar mahasiswa diperoleh $62,25 \%$ pada kategori baik. Secara kuantitatif $61,53 \%$ mahasiswa tuntas, hal ini sudah memenuhi target kebrhasilan yaitu lebih dari 60\% mahasiswa mencapai nilai tuntas. Namun untuk kemadirian belajar mahasiswa masih masuk kategori baik yang belum terlalu signifikan sehingga perlu direncanakan untuk tindakan selanjutnya.

\section{Hasil dan Pembahasan Siklus 3}

\section{Tahap Perencanaan}

Pada tahap ini, telah dipersiapkan instrumen penelitian yang berupa lembar observasi kemandirian belajar mahasiswa dengan menerapkan pembelajaran menggnakan e-modul berbebasis kvisoft flipbook maker soal tes akhir siklus 3, kuis, pembuatan perangkat pembelajaran yang terdiri atas rencana pembelajaran semester (RPS). Materi yang dibahas pada siklus 3 ini adalah Menyelesaikan Program Linier dengan menggunakan metode garsi selidik.

\section{Tahap Pelaksanaan}

Tahap ini adalah pelaksanaan pembelajaran menggunakan e-modul berbasis kvisoft flipbook maker, sehingga data penelitian diperoleh dari hasil observasi kemnadirian belajar mahasiswa dengan menerapkan pembelajaran menggunakan e-modul berbasis kvisoft flipbook maker observer. Adapaun data yang diambil dari tahap ini berupa persentase kemandirian belajar mahasisswa dalam kegiatan pembelajaran serta hasil tes akhir siklus 3. Selengkapnya hasil observasi kemandirian belajar mahasiswa pada siklus 3 seperti tabel berikut.

Tabel 4 Hasil Analisis Kemandirian Belajar Mahasiswa siklus 3

\begin{tabular}{clc}
\hline No. & \multicolumn{1}{c}{ Indikator } & Siklus III \\
\hline 1. & Mengambil inisiatif untuk bertindak & $87,03 \%$ \\
2. & menghargai hasil karya sendiri, & $64,81 \%$ \\
3. & memberdayakan kemampuan yang dimiliki, & $72,2 \%$ \\
4. & memiliki kepercayaan diri & $64,8 \%$ \\
\multicolumn{2}{c}{ Jumlah } & $72,21 \%$ \\
\hline
\end{tabular}




\section{At-Taqaddum}

Vol. 12 No. 1 (2020) 1-12

Berdasarkan tabel diperoleh hasil observasi Kemandirian Belajar Mahasiswa sebesar 72,21\% pada kategori baik. Pada siklus 3 ini persentase setiap indikator mengalami peningkatan. Terdapat 4 Indikator pada kategori baik dan satu indikator dalam kategaori sangat baik. Pada siklus ketiga ini, mahasiswa sudah terbiasa dengan menggunakan e-modul sehingga hampir $90 \%$ perkuliahan hanya dengan membuka emodul. Dosen hanya sebagai fasilitator pada kegiatan perkuliahan. Tugas yang diberikan dosen pun, dikerjakan oleh mahasiswa dengan antusias. Hal ini dibuktikan dengan aktif dan saling bersaing ketika dosen menyajikan masalah untuk diselesaikan di kelas. Hasil belajar mahasiswa pada materi menyelesaikan masalah program linier dengan menggunakan metode garis selidik diperoleh dari res akhir siklus 3 yaitu 20 mahasisswa mendapatkan nilai tuntas dan 6 mahasiswa belum tuntas. Dengan persentase ketuntasan sebesar $76,9 \%$

\section{Tahap Refleksi}

Pada tahap ini dilakukan refleksi atau evaluasi dari pelaksanaan siklus 2. Dari hasil observasi kemandirian belajar mahasiswa diperoleh $72,21 \%$ pada kategori baik. Secara kuantitatif $76,9 \%$ mahasiswa tuntas, hal ini menunjukkan bahwa penelitian sudah berhasil karena sudah meningkat signifikan dari kriteria minimal.

\section{Kesimpulan}

Pembelajaran Program Linier dengan menggunakan e-modul berbasis kvisoft flipbook maker ini dapat meningkatkan kemandirian belajar mahasiswa, hal ini terbukti dari hasil wawancara dengan mahasiswa yang menunjukkan respon positif dari mahasiswa.

\section{Daftar Pustaka}

Budi Sutedjo Dharma Oetomo. E-education; Konsep teknologi dan aplikasi internet pendidikan, Yogyakarta, 2002.

Cristina T. 2015. Importance of Slef Directed Learning. Logos Universality Mentality Eduvation Novelty, Section: Social Science, 2015, IV(1), 37-49

Djaafar Tengku Zahara, Kontribusi Strategi Pembelajaran Terbadap Hasil Belajar, Jakarta Balitbang Dep.diknas, 2001.

Eman Suherman dkk, Strategi Pembelajaran Matematika Kontemporer. Bandung: JICA, 2001.

Fariyani, Q. (2019). Model Pembelajaran Kooperatif Jigsaw untuk Meningkatkan Keaktifan dan Hasil Belajar Siswa MTs Kelas VIII. Jurnal Penelitian Pembelajaran Fisika, 10(2), 133-138. https://doi.org/10.26877/jp2f.v10i2.4026

Fazzlijan M. A. K., Mona M., 2015. The Effectiveness of an Interactive Multimedia Courseware with cooperative mastery approach in enhancing Hihger oerder 
Thinking Skills In learning Cellular Respiration. Procedia-Social and Behavioral Science 176 , 977-984

Hamalik Umar, Kurikulum dan Pembelajaran, Jakarta: PT Bumi Aksara, 1999.

Herman Hudoyo, Pengembangan Kurikulum dan Pembelajaran Matemaika, Malang: UM Press, 2005.

Herman Hudoyo, Mengajar Belajar Matematika, Jakarta: Depdikbud, 1988.

Kunandar.2008. Langkah Mudah Penelitina Tindkan Kelas Sebagai Pengembangan Profesi Guru. Jakart:PT Rajawali Press.

Lexy J. Moloeng, Metodologi Penelitian Kualitatif, Bandung: PT Remaja Rosdakarya, 2002.

Muhibin Syah, Psikiologi Pendidikan dengan Pendekatan Baru, Bandung: Rosda Karya, 2004.

Nana Sudjana, 2000, Dasar-dasar Proses Belajar Mengajar, Bandung: Sinar Baru Algesindo.

Nana Sudjana dan Ahmad Rivai. 2013. Media Pengajaran. Bandung:sinar Baru:Algensindo Offset

Nasution, Berbagai Pendekatan Dalam Proses Belajar Mengajar, Bandung PT Bina Aksara, 1984.

Nurfalah, E. (2019). Optimalisasi E-Learning berbasis Virtual Class dengan Google Classroom sebagai Media Pembelajaran Fisika. Physics Education Research Journal, 1(1), 46-55. https://doi.org/10.21580/perj.2019.1.1.3977

Oemar Hamalik, Kurikulum dan Pembelajaran, Jakarta: Bumi Aksara, 1999.

Sadiman, A. dkk. 2014. Media Pendidikan, Pengertian, Pengembangan dan Pemanfaatannya. Jakarta:Pustekkom Dikbud

Slameto, Belajar dan Faktor-Faktor yang Mempengarubinya, Jakarta: PT Rineka Cipta, 2003.

Sumadi Suryabrata, Psikologi Pendidikan,Jakarta: PT Raja Grafindo Persada, 1995.

Sumarna Surapranata, Analisis, Validitas, Reliabilitas, dan Interpretasi hasil Tes: Implementasi Kurikulum 2004, Bandung: PT Remaja Rosdakarya, 2005.

Suparlan, Menjadi Dosen Efektif, Yogyakarta: Hikayat Publishing, 2005.

Vianney Lara P., Efrain B.Q., Miguel A.R.A. (2015). An Innovative Self Learning Approach to 3D Printing using Multimedia and Augmented Reality on Mobile Devices. Procedia Computer Science 75(2015).59-65

Winkel Psikologi dan Evaluasi Belajar, Jakarta: Gramedia, 1983.

Sukardjono, Penelitian Tindakan (PT) atau Action Research (AR) atau Penelitian Tindakan Kelas (PTK) atau Classroom Action Research (CAR), Makalah yang disajikan pada Supervisi Pengajaran Matematika untuk Sekolah Menengah tanggal 30 September s.d 14 Oktober 2001 di PPPG Matematika Yogyakarta. 


\section{At-Taqaddum}

Vol. 12 No. 1 (2020) 1-12

Sukayati, Penelitian Tindakan Kelas, Makalah yang disampaikan pada Diklat Dosen Pemandu Mata Pelajaran Matematika SD tanggal 5 s.d 20 Agustus 2002 di PPPG Matematika Yogyakarta.

Wina Sanjaya, 2007, Strategi Pembelajaran Berorientasi Standar Proses Pendidikan, Jakarta: Kencana Prenada Media Grup 